\title{
Acute Liver Failure and Myelosuppression due to Parvovirus B19 Infection: A Case Report
}

\author{
Jian Qi Lian ${ }^{\mathrm{a}}$, Ye Zhang ${ }^{\mathrm{a}}$, Li Liu ${ }^{\mathrm{b}}$, Xian Guang Bai ${ }^{\mathrm{a}}$, Zhi Jun Liang, \\ Yan Yan Zhao ${ }^{\mathrm{a}}$, Ying Min Liang ${ }^{\mathrm{b}}$
}

\begin{abstract}
Parvovirus B19 has been associated with different diseases, such as erythema infectiosum, arthropathy and transient aplastic crisis. However, parvovirus B19 infection presenting as hepatic dysfunction and myelosuppression is rarely reported in adult patients. Herein, we report an adult case of acute parvovirus B19 infection presented with acute liver failure and myelosuppression. After being treated with gamma globulin, the patient's liver function and bone marrow test improved. We conclude that the parvovirus B19 infection should be considered as a possible cause of acute liver injury and bone marrow suppression. The antibody for B19 virus should be routinely tested in patients with liver dysfunction and/or myelosuppression of unclear etiology.
\end{abstract}

Key words: Parvovirus B19; Acute Liver Failure; Myelosuppression

\section{Introduction}

Parvovirus B19, a member of the family Parvoviridae, subfamily Parvovirinae, genus Erythrovirus, is a small, single-stranded DNA virus with approximately 5,000 nucleotides that codes for two major structural or capsid proteins, VP1 and VP2, and one nonstructural protein, NS1. B19 virus has been implicated in a wide spectrum of illnesses, which are transmitted via blood products or through aerosolized

Manuscript accepted for publication February 24, 2009.

${ }^{a}$ Center of Infectious Diseases, ${ }^{b}$ Department of Hemotology, Tangdu Hospital, The Fourth Military Medical University, Xi'an, Shaanxi province, China

${ }^{\mathrm{c} C}$ Corresponding author: lianjq@fmmu.edu.cn

doi:10.4021/gr2009.03.1278 droplets and fomite contamination. B19 causes erythema infectiosum (Fifth disease), which has been suggested as one of the causes of acute non-A, non-E hepatitis in children infection [1]. Parvovirus B19 infection in adults often manifests as arthropathy, particularly in females [2]. B19 infection is also associated with transient aplastic crisis by destroying the erythroid precursor pool in patients with chronic hemolytic anemia, such as sickle cell disease or hereditary spherocytosis [3]. In immunocompromised patients, symptomatic B19 infection can persist for months or even years [4]. On the other hand, asymptomatic infection has been reported to occur in about one-quarter of immunocompetent adults [5]. Most infections occur during childhood, resulting in anti-B19 IgG prevalence of about $60 \%$ at the age of 12 years [6]. Uncommon manifestations of B19 infection include dermatological, hematological, vascular, and neurological presentations [7]. Liver involvements in B19 infection are uncommon, especially in adult patients [8]. Herein, we report an adult case of parvovirus B19 infection with acute liver failure and myelosuppression.

\section{Case report}

A 34-year-old female, without any positive medical history, reported malaise and fever of 23 days, and jaundice of 1 week. In addition to sporadic doses of paracetamol and penicillin, she had not received any other treatment before admission. Examination upon admission revealed slight hepatomegaly and splenomegaly. Maculopapules were found in cervical and thoracic areas. However, no anemia, palpable cervical lymph nodes or other remarkable physical signs were observed. Blood alanine aminotransferase (ALT) was $307 \mathrm{U} / \mathrm{L}$ (normal range, NR, 0 - $40 \mathrm{U} / \mathrm{L}$ ); aspartate aminotransferase (AST), $444 \mathrm{U} / \mathrm{L}(\mathrm{NR}, 0-30 \mathrm{U} / \mathrm{L})$; gamma-glutamyl transferase (GGT), $97 \mathrm{U} / \mathrm{L}(\mathrm{NR}, 0$ - $50 \mathrm{U} / \mathrm{L})$; alkaline phosphatase (ALP), $142 \mathrm{U} / \mathrm{L}$ (NR, 45 - 132U/L); total bilirubin (TBIL), $195.70 \mu \mathrm{mol} / \mathrm{L}$ (NR, $3.0-22.0 \mu \mathrm{mol} / \mathrm{L}$ ); direct bilirubin (DB), $183.80 \mu \mathrm{mol} / \mathrm{L}(\mathrm{NR}, 0.0-5.0 \mu \mathrm{mol} / \mathrm{L}$ ); total protein (TP), $54.4 \mathrm{~g} / \mathrm{L}$ (NR, $60-80 \mathrm{~g} / \mathrm{L}$ ); albumin (ALB), $26.9 \mathrm{~g} / \mathrm{L}(\mathrm{NR}, 35-50 \mathrm{~g} / \mathrm{L})$, indirect bilirubin and globulin were normal. White blood cell (WBC) count was $3.75 \times 10^{9}$ 


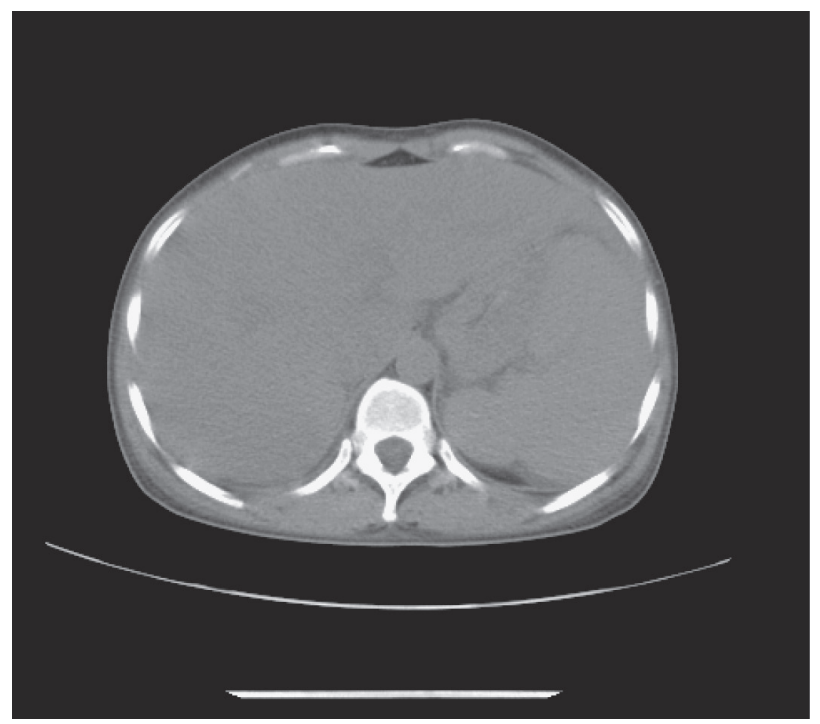

Figure 1. Abdominal computed tomography (CT). CT scan showed lower density of liver parenchyma and splenomegaly.

/L (84.2\% neutrophils, $11.5 \%$ lymphocytes, $4 \%$ monocytes, $0.3 \%$ eosinophils, $0 \%$ basophlis), and red blood cell (RBC), hemoglobin and platelet counts were within normal limits. Thrombin time was 32.2 seconds (NR, $14-21 \mathrm{sec})$; prothrombin time (PT), $22.8 \mathrm{sec}(\mathrm{NR}, 11-14 \mathrm{sec})$; international normalized ratio (INR) 2.35; activated partial thromboplastin time (APTT), 36.1 second (NR, 25 - 36 second); fibrinogen, $0.86 \mathrm{~g} / \mathrm{L}(\mathrm{NR}, 2-4 \mathrm{~g} / \mathrm{L})$. Erythrocyte sedimentation rate (ESR) was normal. Antinuclear antibodies and rheumatoid factor were negative. Blood culture was negative.

Abdominal echography revealed homogeneous enlargement of spleen, but revealed the enlargement of the only right lobe of liver. Chest and abdominal computed tomography (CT) scan showed pachynsis of right pleura, interstitial change of lobus inferior pulmonis, and lower density of liver parenchyma and splenomegaly (Fig. 1). Serology was negative for typhus; typhoid fever; tuberculosis; syphilis; human syncytial virus; hepatitis A, B, C, D, and $\mathrm{E}$ virus; human immunodeficiency virus; cytomegalovirus; and Epstein-Barr virus. The patient was given antibiotics and adjuvant hepatic treatments for 1 week. The fever and maculopapules subsided, but the jaundice and liver function test still unimproved, anemia existed. Blood chemistry showed ALT 236 U/L, AST 124U/L, GGT 106 U/L, TBIL $530.6 \mu \mathrm{mol} / \mathrm{L}$, DB $376.6 \mu \mathrm{mol} / \mathrm{L}$. WBC count, $0.25 \times 10^{9} / \mathrm{L}$ (4\% neutrophils, $84 \%$ lymphocytes, $12 \%$ monocytes, $0 \%$ eosinophils, $0 \%$ basophlis); RBC count, $3.37 \times 10^{12} / \mathrm{L}$; hemoglobin $87 \mathrm{~g} / \mathrm{L}$; platelet $10 \times 10^{9} / \mathrm{L}$. The bone marrow aspirate showed lack of red blood cell and platelet. Bone marrow biopsy revealed decrease in all three hemopoeitic precursors, no megakaryocytes were found, mild hyperplasia of fibrous tissue with invasion of neutrophil was detected, no apparent pathogen and malignancy was noticed (Fig. 2). IgM and IgG antibodies against parvovirus B19 were positive. The patient was treated with gamma globulin, liver function and bone marrow test results improved. In a follow-up visit 3 weeks after, patient was asymptomatic, the clinical blood test was normal, and liver function was normalized.

\section{Discussion}

In this report, we describe a 34-year-old female patient, without obvious underlying disease, developed acute liver failure and myelosuppression following B19 virus infection. Parvovirus has been associated with acute hepatic failure, especially in children $[9,10]$, patients with parvovirus associated liver failure seems to do better than those secondary to other etiology [11]. However, cases of liver failure in adults due to parvovirus infection are rarely reported. Our case, as well as others reported in adults $[12,13]$, suggests that liver involvement in parvovirus B19 infection appears less severe than that in pediatric patients.

The pathophysiology of hepatic lesion in B19 infection is still unclear. Some have proposed an immunologically mediated mechanism and others have postulated a direct viral cytopathic effect on hepatocytes [1]. Basic research has demonstrated that B19 virus is capable of infecting and inducing apoptosis in both primary hepatocytes and a liver-derived cell line [14]. B19 virus induced apoptosis may proceed through a caspase 3-dependent pathway, but not the caspase 8 activity. The effect of B19 virus on HepG2 cells is a result of an apoptotic pathway initiated within the infected cell rather than as a result of an exogenous signal of a tumor necrosis factor (TNF) receptor family member [14]. A candidate molecule for affecting apoptosis in HepG2 cells is the B19 virus nonstructural protein NS1, which is a multifunctional protein with endonuclease, helicase, nucleotide

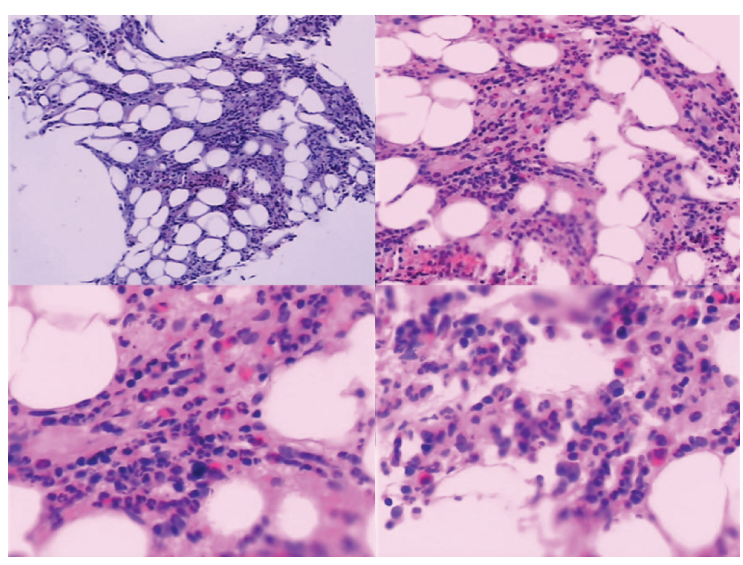

Figure 2. Bone marrow findings on admission. The decrease in all three hemopoietic precursors, no megakaryocytes, with mild hyperplasia of fibrous tissue with invasion of neutrophils. No apparent pathogen and malignancy were noticed. 
triphosphate binding, and transactivating activities. B19 virus causes apoptosis of hepatocytes through NS1 expression. NS1 induces apoptosis in HepG2 cells independently of the presence of full-length viral genomic DNA or other viral proteins, this confirms that NS1 is sufficient to induce apoptosis [15]. NS1 transfection induces activation of caspases 3 and 9, these caspases are necessary for optimal induction of apoptosis. Involvement of the caspase 9 pathway is typical of apoptosis induced by internal stress, in contrast to apoptosis induced by TNF- $\alpha$ [15].

The anemia and myelosuppression could be secondary to parvovirus B19 infection acquired during the course of the disease. This is possible due to the marked trophism of parvovirus to the erythroid precursor $[1,16]$. The most plausible explanation for the pathogenesis of myelosuppression is that some immune-mediated mechanisms induce a disturbance in the bone marrow and lead to decreased hematopoiesis. The B19 virus is well demonstrated to infect the erythroid progenitor cells and is associated with aplastic crisis in patients with chronic hemolysis [17]. The in vitro and in vivo analysis showed that the B19 virus infects mainly the erythroid progenitor cells, while other progenitor cells may also be affected by inefficient viral replication [18]. The NS1 both induces production of TNF- $\alpha$ and sensitizes cells to killing by TNF- $\alpha$ in erythroid cells [15].

Acute liver failure with myelosuppression due to parvovirus B19 infection is extremely rare in adult patients, although there are isolated cases reported on the presentation with severe hemophagocytosis and acute hepatitis associated with parvovirus infection in children [10]. We believe that parvovirus B19 infection should be considered a possible cause of liver injury, the antibody of B19 virus should be routinely tested in patients with liver dysfunction of unclear etiology.

\section{Acknowledgements}

The authors declare no conflicts of interest.

\section{References}

1. Yoto Y, Kudoh T, Haseyama K, Suzuki N, Chiba S. Human parvovirus B19 infection associated with acute hepatitis. Lancet 1996;347:868-869.

2. Naides SJ, Scharosch LL, Foto F, Howard EJ. Rheumatologic manifestations of human parvovirus B19 infection in adults. Initial two-year clinical experience. Arthritis Rheum 1990;33:1297-1309.

3. Cubel RC, Valadao MC, Pereira WV, Magalhaes MC, Nascimento JP. Aplastic crisis due to human parvovirus
B19 infection in hereditary hemolytic anaemia. Rev Inst Med Trop Sao Paulo 1992;34:479-482.

4. Kurtzman GJ, Ozawa K, Cohen B, Hanson G, Oseas R, Young NS. Chronic bone marrow failure due to persistent B19 parvovirus infection. N Engl J Med 1987;317:287294.

5. Woolf AD, Campion GV, Chishick A, Wise S, Cohen BJ, Klouda PT, Caul O, et al. Clinical manifestations of human parvovirus B19 in adults. Arch Intern Med 1989;149:1153-1156.

6. Cohen BJ, Buckley MM. The prevalence of antibody to human parvovirus B19 in England and Wales. J Med Microbiol 1988;25:151-153.

7. Naides SJ. Parvoviruses. In: Specter S, Lancz G eds. Clinical virology manual, 2nd edn. Elsevier: Essex, 1992; 547-69.

8. Hillingso JG, Jensen IP, Tom-Petersen L. Parvovirus B19 and acute hepatitis in adults. Lancet 1998;351:955956.

9. So K, Macquillan G, Garas G, Delriviere L, Mitchell A, Speers D, Mews C, et al. Urgent liver transplantation for acute liver failure due to parvovirus B19 infection complicated by primary Epstein-Barr virus and cytomegalovirus infections and aplastic anaemia. Intern Med J 2007;37:192-195.

10. Dutta U, Mittal S, Ratho RK, Das A. Acute liver failure and severe hemophagocytosis secondary to parvovirus B19 infection. Indian J Gastroenterol 2005;24:118-119.

11. Sokal EM, Melchior M, Cornu C, Vandenbroucke AT, Buts JP, Cohen BJ, Burtonboy G. Acute parvovirus B19 infection associated with fulminant hepatitis of favourable prognosis in young children. Lancet 1998;352:17391741 .

12. Tsuda H. Liver dysfunction caused by parvovirus B19. Am J Gastroenterol 1993;88:1463.

13. Diaz F, Collazos J. Hepatic dysfunction due to parvovirus B19 infection. J Infect Chemother 2000;6:63-64.

14. Poole BD, Karetnyi YV, Naides SJ. Parvovirus B19induced apoptosis of hepatocytes. J Virol 2004;78:77757783.

15. Poole BD, Zhou J, Grote A, Schiffenbauer A, Naides SJ. Apoptosis of liver-derived cells induced by parvovirus B19 nonstructural protein. J Virol 2006;80:4114-4121.

16. Langnas AN, Markin RS, Cattral MS, Naides SJ. Parvovirus B19 as a possible causative agent of fulminant liver failure and associated aplastic anemia. Hepatology 1995;22:1661-1665.

17. Mortimer PP, Cohen BJ, Buckley MM, Cradock-Watson JE, Ridehalgh MK, Burkhardt F, Schilt U. Human parvovirus and the fetus. Lancet 1985;2:1012.

18. Kurtzman G, Young N. Viruses and bone marrow failure. Baillieres Clin Haematol 1989;2:51-67. 